\title{
Studies on Tongue of Reptilian Species Psammophis sibilans, Tarentola annularis and Crocodylus niloticus
}

\author{
Estudios sobre la Lengua de las Especies de Reptiles \\ Psammophis sibilans, Tarentola annularis y Crocodylus niloticus
}

Hassan I.H. El-Sayyad; Dalia A. Sabry; Soad A. Khalifa; Amora M. Abou-El-Naga \& Yosra A. Foda

EL-SAYYAD, H. I. H.; SABRY, D. A.; KHALIFA, S. A.; ABOU-EL-NAGA, A. M. \& FODA, Y. A. Studies on tongue of reptilian species Psammophis sibilans, Tarentola annularis and Crocodylus niloticus. Int. J. Morphol., 29(4):1139-1147, 2011.

SUMMARY: Three different reptilian species Psammophis sibilans (Order Ophidia), Tarentola annularis (Order Squamata and Crocodylus niloticus (Order Crocodylia) are used in the present study. Their tongue is removed and examined morphologically. Their lingual mucosa examined under scanning electron microscopy (SEM) as well as processed for histological investigation. Gross morphological studies revealed variations of tongue gross structure being elongated with bifurcated end in $P$. sibilans or triangular flattened structure with broad base and conical free border in T. annularis or rough triangular fill almost the floor cavity in $C$. niloticus. At SEM, the lingual mucosa showed fine striated grooves radially arranged in oblique extension with missing of lingual papillae. Numerous microridges are detected above the cell surfaces in P. sibilans. T. annularis exhibited arrangement of conical flattened filiform papillae and abundant of microridges. However in C. niloticus, the lingual mucosa possessed different kinds of filiform papillae besides gustatory papillae and widespread arrangement of taste buds. Histologically, confirmed SEM of illustrating the lingual mucosa protrusion of stratified squamous epithelium in P. sibilans and presence of apical taste buds in conical filiform papillae of T. annularis. The lingual mucosa of $C$. niloticus revealed different forms of both filiform and gustatory papillae.

KEY WORDS: Reptilian species; Lingual mucosa; SEM; Light microscopy.

\section{INTRODUCTION}

Reptiles may live in aquatic or terrestrial habitat. The most interesting features of the histological structures of the reptilian tongues reflect adaptations to a dry habitat or to seawater, but stratification and keratinization of the lingual epithelium are the most common features (Iwasaki, 1990; Iwasaki \& Kumakura, 1994). Reptilian tongues are characterized by morphological and functional variations among species. Squamate reptiles can identify and evaluate foods using chemical cues sampled by tongue-flicking (Cooper, 1995, 2003). Snakes and some other squamates use forked tongues for chemo- and mechanoreception (Schwenk, 1994, 1995; Bels et al., 1994). During a probing action, the tongue protrudes, oscillates (flicks) while collecting airborne and substrate-fixed chemical particles and subsequently retracts (Ulinski, 1972; Gove, 1979). Little is known about the structural variations of lingual mucosa of reptilian species due to the huge number of populations. The present study aimed to illustrate a comparative morphological, histological, ultrastructural and functional variations of Psammophis sibilans, Tarentola annularis and Crocodylus niloticus.

\section{MATERIAL AND METHOD}

Experimental animals. Three different reptilian species were selected (Tarentola annularis and Crocodylus niloticus) are collected from Abou-Raoash desert of Egypt. These species were identified according to Gauthier et al. (1989). These species have the following classification:

- Psammophis sibilans var, subtaeniatus Peter, 1882; Order: Ophidia family: colubridae; Genus: psamophis Boie, 1826.

- Tarentola annularis (black gecko): Order: Squamata; Suborder: Lacertillia; Family: Gekkonidae; Subfamily: Gekkoninae.

- Crocodylus niloticus Laurenti, 1768: Subclass Diapsida; 
Order Crocodylia; Family Crocodylidae; Genus Crocodylus.

The reptilian species are sacrificed according to the local experimental animal ethics committee, dissected and tongue is removed and processed for investigation using the following parameters:

Morphological studies: The tongue specimens are removed, photographed and described.

Histological studies: Fresh tongue specimens are immediately fixed in $10 \%$ formol saline, dehydrated in ascending grades of ethyl alcohol, cleared in zylol and mounted in molten paraplast 58-62 C. Five $\mu \mathrm{m}$ thick histological sections are cut and stained with haematoxylin and eosin. Samples are investigated by bright field light microscopy. The thickness of lingual mucosa is measured. The thickness of horny layer is determined and correlated with whole thickness of lingual mucosa.

Scanning electron microscopic study: For topographic studies, extra tongue specimens are fixed in 10\% formal saline for 24 hours, followed by dehydration in ascending ethanol series (50, 70, 90 and 100\%). The specimens were carefully mounted on aluminium stages with double-sided carbon tape, and critical point dried. The samples are mounted on metal stubs, coated with gold and observed at various different angles with a Jeol scanning electron microscope at accelerating voltages of 5 or $10 \mathrm{kV}$.

\section{RESULTS}

\section{Morphological observation}

Macroscopically, C. niloticus tongue occupied the greater part of the floor of the oral cavity (apart from the rostral plate over the symphysis of the dentary bones). It is firmly fixed in the oral cavity. The tongue appeared roughly triangular in shape, being much broader caudally more than its free border. The dorsal surface displayed numbers of large, dome-shaped structures which were concentrated in median part of the tongue. The centrally positioned structure typical of these units represented a flattened disc of thickened epithelium. The surface of the tongue was generally creamyyellow in colour and had a slightly spongy texture even in the fixed specimens (Fig. 1A).

Psammophis sibilans tongue, divided into three portions; anterior free bifurcated tongue tips followed by middle portion which protrudes out of the mouth during tongue flicking, and a posterior portion of the tongue that

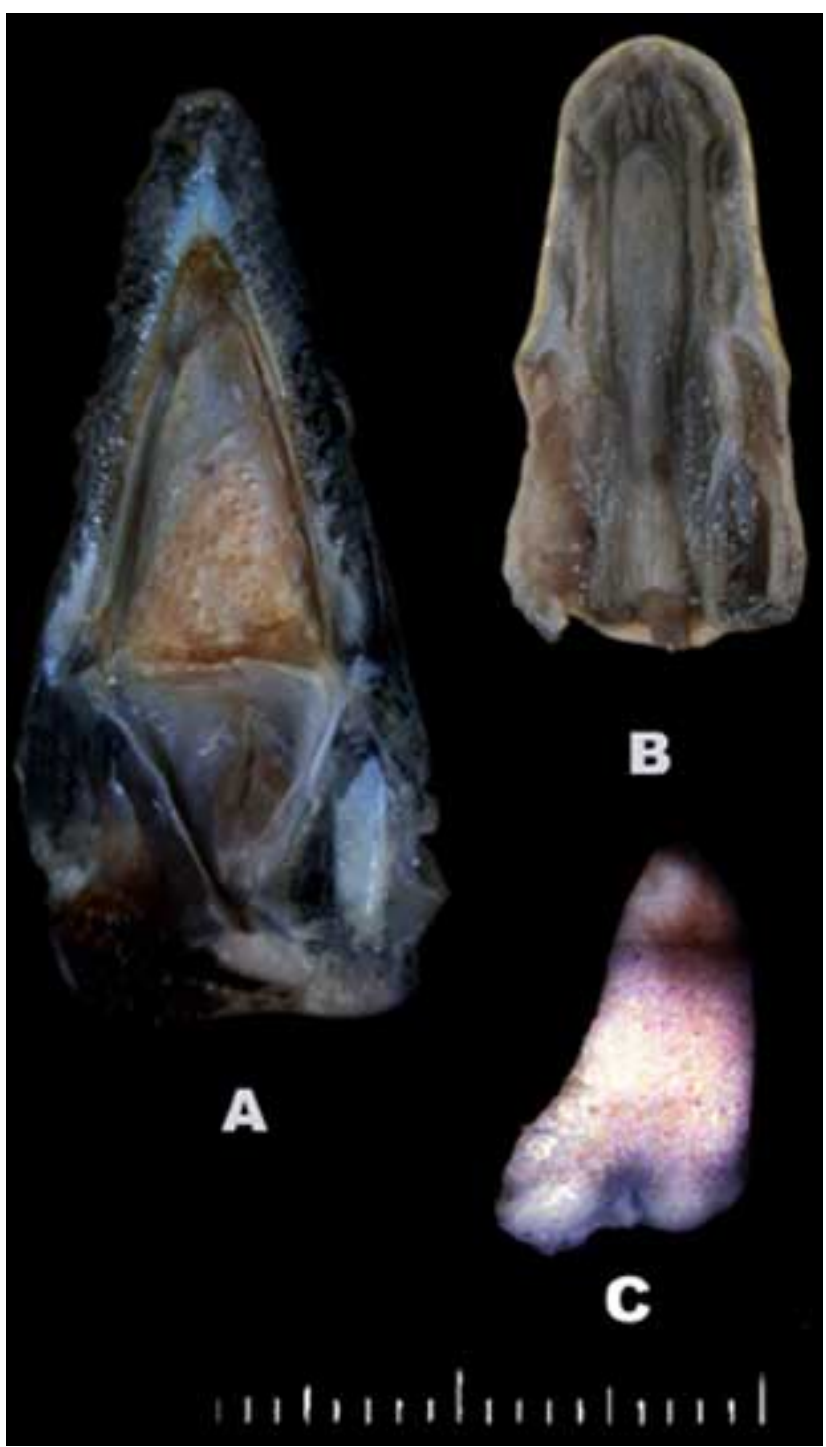

Fig. 1. A-D. Photomacrographs of dorsal view of tongue of $C$. niloticus (A), P. sibilans (B) and T. annularis.

remained almost entirely within the mouth during protrusion. The tongue is suspended in the floor of the mouth by a folded tongue sheet that is dorsally stiffened by the larynx and trachea (Fig. 1B).

T. anularis tongue appeared triangular flattened structure with broad base and conical free border (Fig. 1C).

\section{Scanning electron microscopic (SEM) observations.}

SEM of the dorsum tongue surface revealed varying lingual mucosa structural components of studied species.

In Psammophis sibilans, the median sulcus is located on the median dorsal surface of the tongue as a deep depression. Fine striated grooves radially arranged in oblique 
extension with slight decrease of the median sulcus in the distal tongue portion. Intercellular borders were clearly observed. The outline of each cell in dorsal view is either polygonal or hexagonal. Most of the surface of the bifurcated part of the tongue was relatively smooth. Microridges are densely distributed on the epithelial cell surface of the lingual body. The tongue is covered by numerous projections called microfacets circumscribed by regularly spaced pores (Fig.2 A-B) .

In Tarentola annularis, conical flattened filiform papillae are compactly distributed all over the tongue surface. Their apical surfaces are covered with keratinized sheets. The lingual papillae surfaces possessed hexagonal structures with widespread of microridges and microvilli. The intercellular borders become elevated (Fig. 2 C-D).

In River Nile Crocodylus niloticus, the tongue surface composed of a number of clearly demarcated round to angular units. The lingual papillae take either concave and convex structures with deep cleft between them. Round to polygonal-shaped units with a prominent centrally positioned pore are detected in the posterior two-thirds of the tongue. A
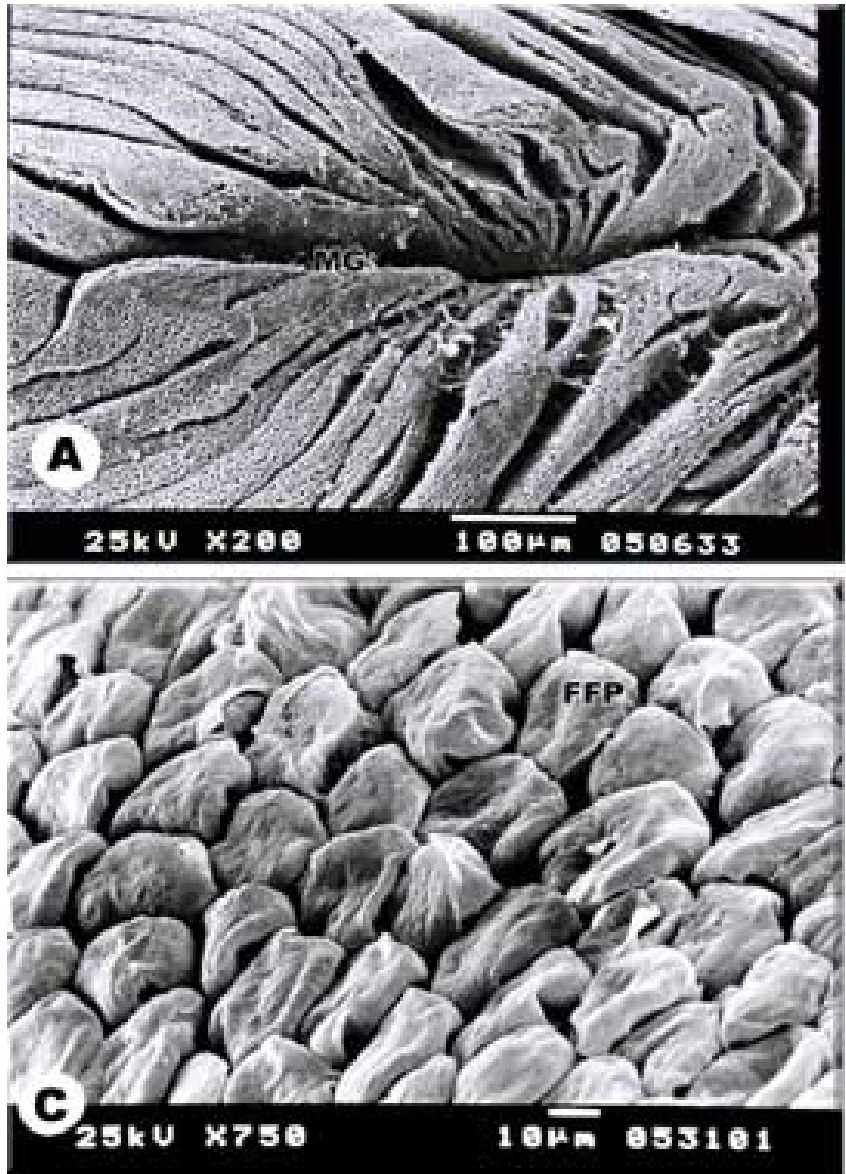

number of grooves radiated outwards around the pore. The grooves varied in lengths. Small spherical structures semilike fungiform papillae with approximate length reached to $8.5 \mu \mathrm{m}$ with central nipple-like surface extensions. There are more than one flattened disc-shaped structure semilike circumvallate papillae lengthened 3-5 $\mu \mathrm{m}$. The lingual papillae displayed a complicated array of microridges, giving the surface a sponge-like appearance (Fig. 3A-F).

\section{Histological observations}

In Psammophis sibilans, the anterior free part is forked. The lingual mucosa formed the superficial layer. Underneath it, a loose connective tissue infiltrated inbetween the blood vessels. In both forked region, bundles of striated muscles are distributed. Near the junction of forked tongue, a cartilage compartment is observed. The forked tongue region possessed much more branched glandular epithelial sheath. The lingual mucosa lined by a single epithelial cell layer formed mainly of glandular cells. The glandular epithelial cells protruded forming lingual structure similar to conical lingual papillae but with abundant blood vessels and less dense connective tissue core. There was no

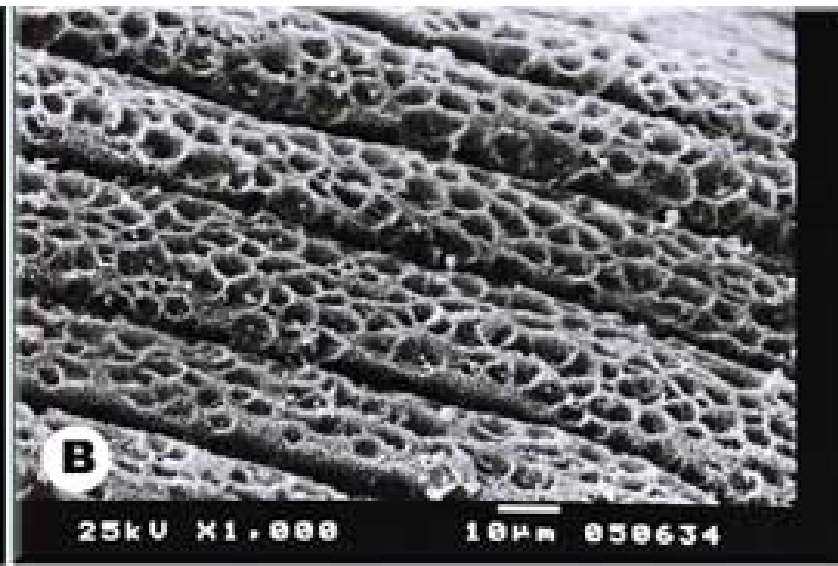

Fig. 2. A-D. SEM of lingual mucosa of $P$. sibilans (A-B) and T. annularis (C-D). FFP: Filiform papilla, Ke: keratinization. 

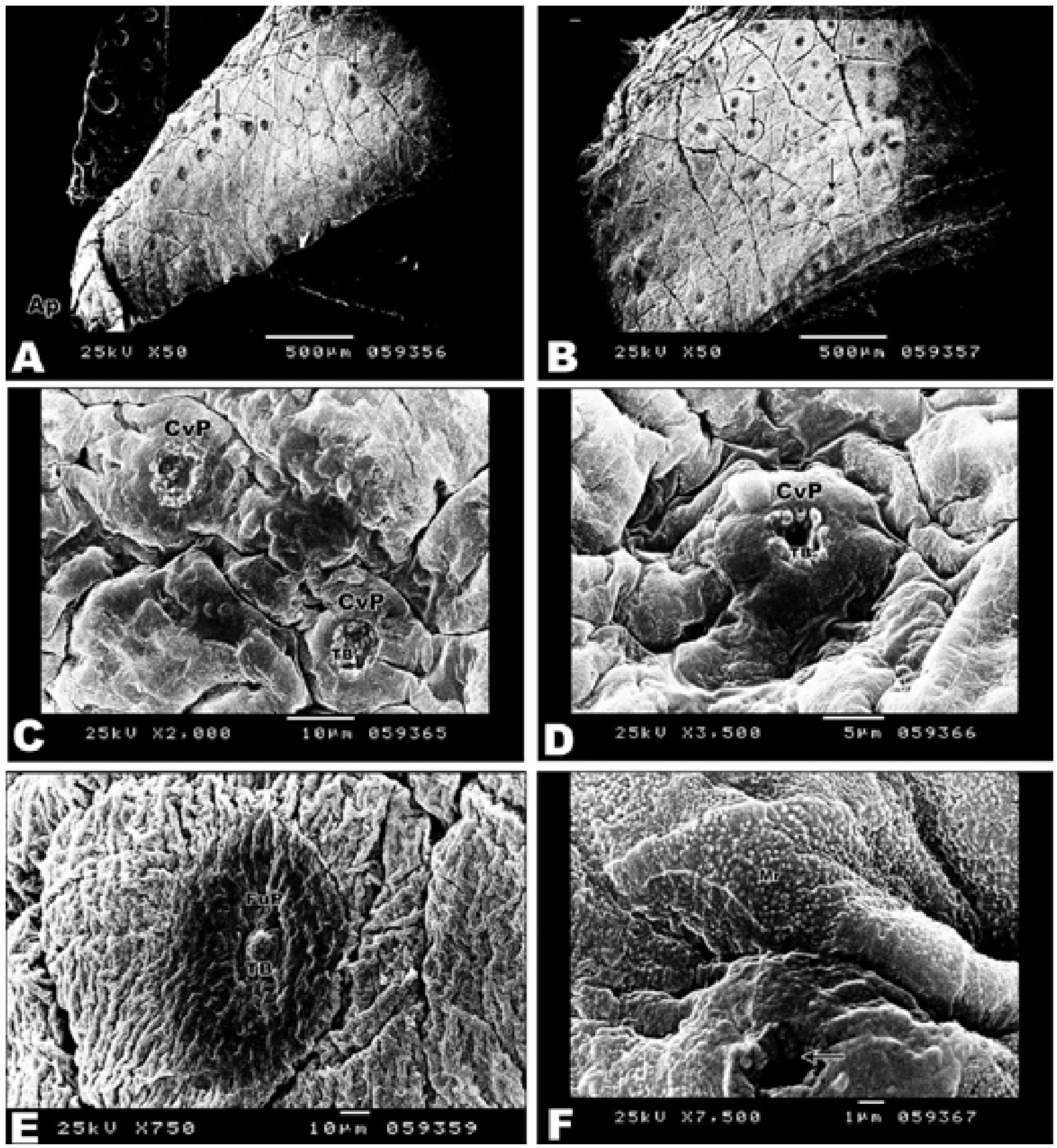

Fig. 3. A-F. SEM of lingual mucosa of C. niloticus. A and B. Showing mucous gland opening and grooves perpendicular to longitudinal axis. C and D. Showing vallate papillae with superficial taste buds. E. Showing fungiform papillae. F. Showing microridges. CVP: circumvallate papilla with apical taste bud pore.

keratinization of the lingual mucosa. Underneath the lingual mucosa the whole length of tongue region, alternating curved ring rode-shaped cartilaginous structures were regularly oriented up-and downwards and tied with each other by a thin connective tissue layer (Fig. 4A-C).
In Tarentola annularis, the lingual mucosa is composed mainly of conical filiform lingual papillae, distributed all over the widest area of the lingual body. The tips of the papillae possessed curved pointed edge toward the tongue root. The core of each papilla lamina propria is composed of collagenous 

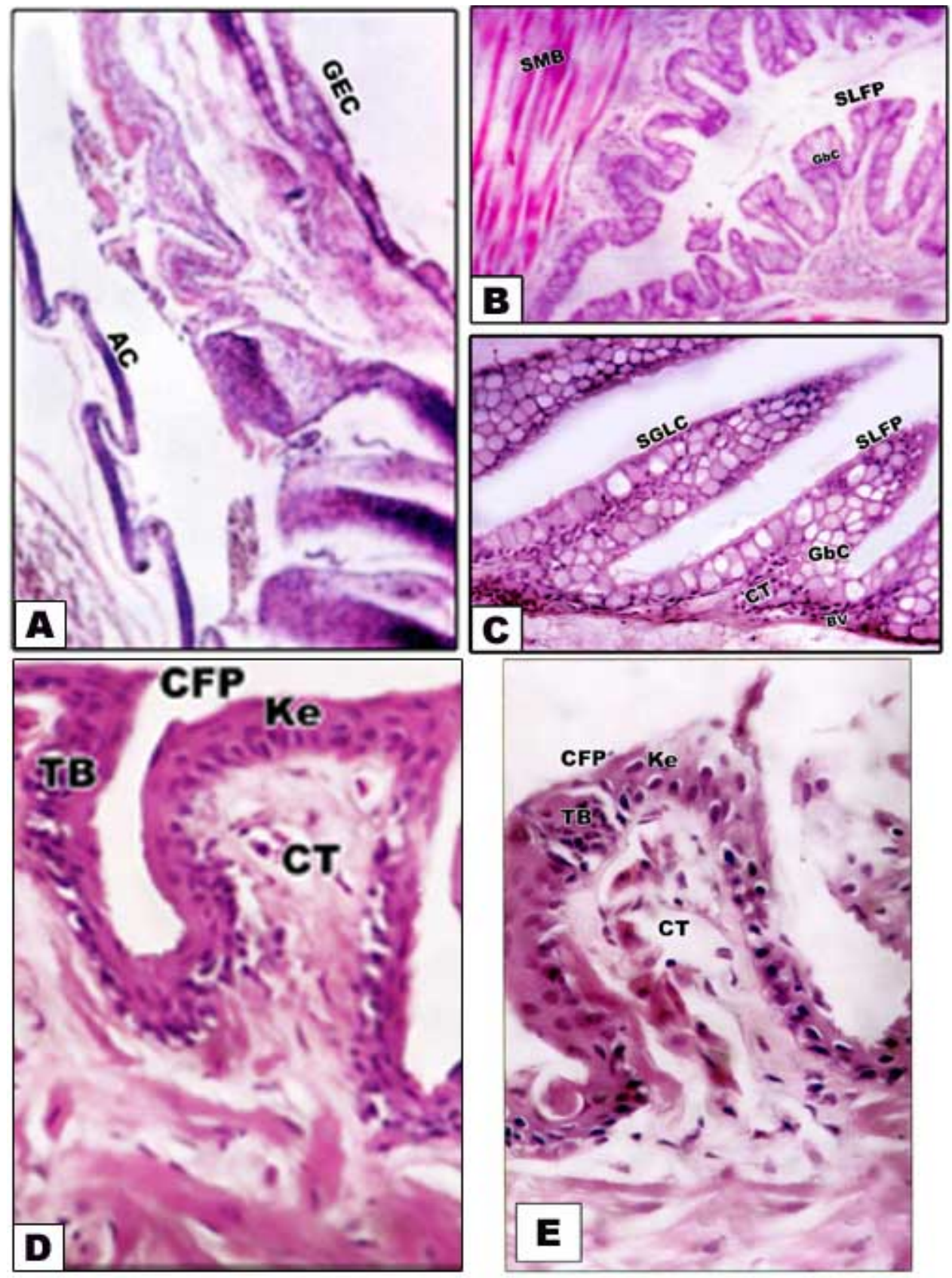

Fig. 4. A-G. Photomicrographs of longitudinal histological sections of lingual mucosa. AD: P. sibilans. A. Showing forked tongue. B. Forked tongue with internal compartment of longitudinal muscle. C. Showing down and upward of articulated cartilage. D. Showing stratified lingual mucosa. E. G. gopherus showing cylindrical papilla. FG. T. annularis showing conical filiform papilla with apical taste buds. AC: Articulated cartilage; C: Cartilage; CFP: Conical filliform papillae; CT: Connective tissue; CvP: Circumvallate papillae; FFP: Filliform papillae; GEC: Glandular epithelial cell; Ke: Keratinization; SGLC: Slender glandular cell; SLFP: slender filiform papillae; SMB: Smooth muscle bundles; TB: Taste buds. H-E (A-C: X160, D-F: X250, G: X400). connective tissue fibers with centrally prominent blood vessels. Few numbers of conical papillae exhibited the presence of apical taste buds (Fig. 4. D-E).

In Nile river Crocodylus niloticus, the lingual body carried numerous forms of filiform papillae. The first one situated around the gustatory circumvallate papilla facing each other like a flower and appeared in the form of fingerlike protrusion. The others take either small conicalstructure or flattened ones. Although most of the filiform papillae possessed pointed edge facing the tongue root, some of them belonging to either conical or flattened form showed apical pointed edge facing each other. The gustatory papillae were firstly recognized in Crocodylus niloticus and included two forms; fungiform and circumvallate papillae. The fungiform papillae possessed three apical small taste buds, while the vallate papillae showed numerous dorso-lateral arrangement of taste buds. The gustatory papillae were enclosed by dense connective tissue core rich in blood vessels (Fig. 5.A-F). 

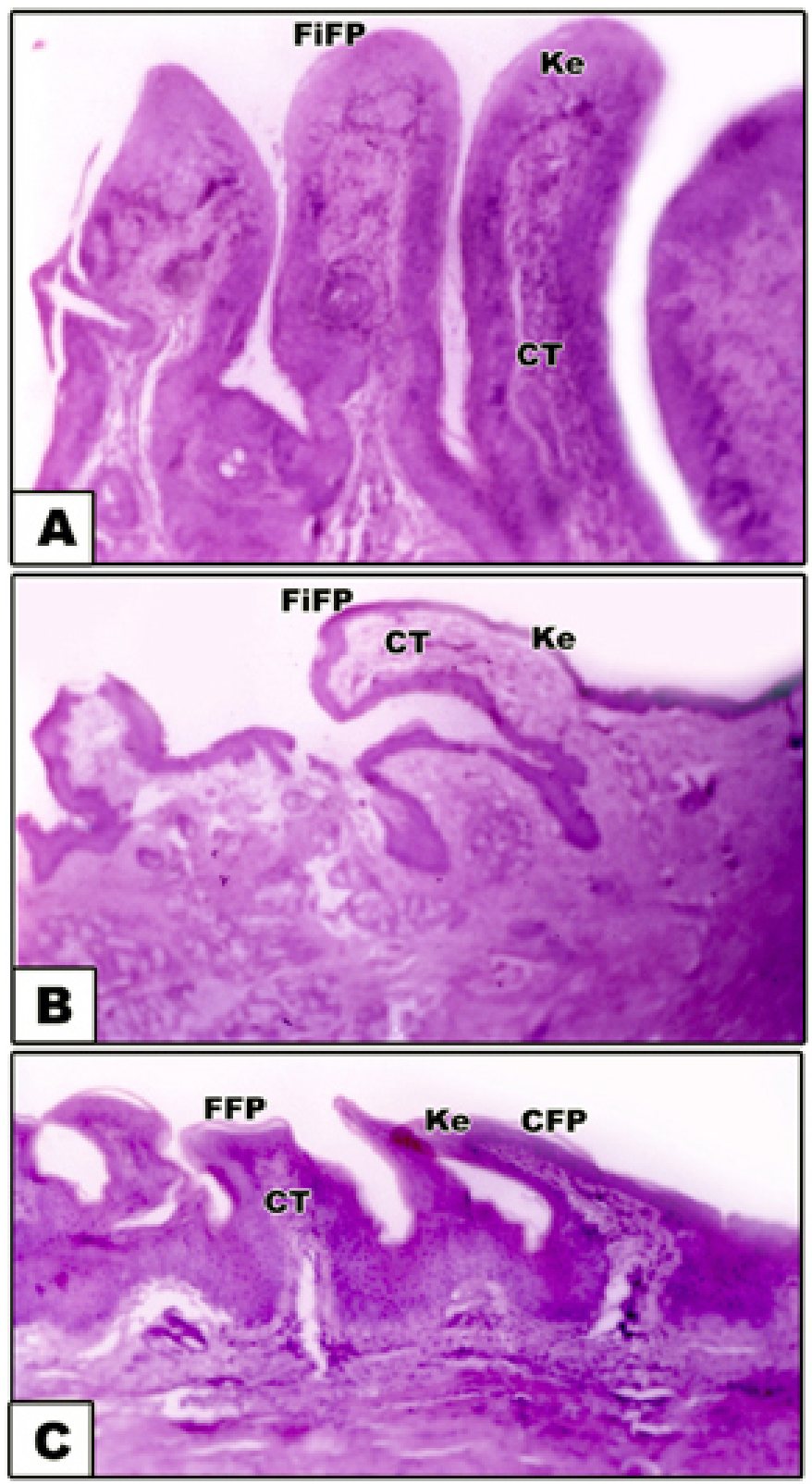

Fig. 5. A-G. Photomicrographs of longitudinal histological sections of lingual mucosa of C. niloticus. A-C. Showing filiform papillae of different forms. D-E Showing vallate papillae encircled by filiform papillae. The gustatory papilla show parietal arrangement of taste buds. CFP: Conical filiform papillae; CT: Connective tissue; CvP: Circumvallate papillae; FFP: Filiform papillae; Ke: Keratinization; TB: Taste buds. H-E (A-D: X160, E: X250, F: X400).

\section{DISCUSSION}

From the present work, the tongue macroscopic structure of the selected vertebrate species of reptilian, aves and mammals widely varied between species. According to (McDowell, 1972; Smith \& Mackay, 1990), the snake tongue, divided into three portions; proximal free bifurcated tongue apex and medium region which are mobile and facilitated protrusion during tongue flicking, meanwhile the
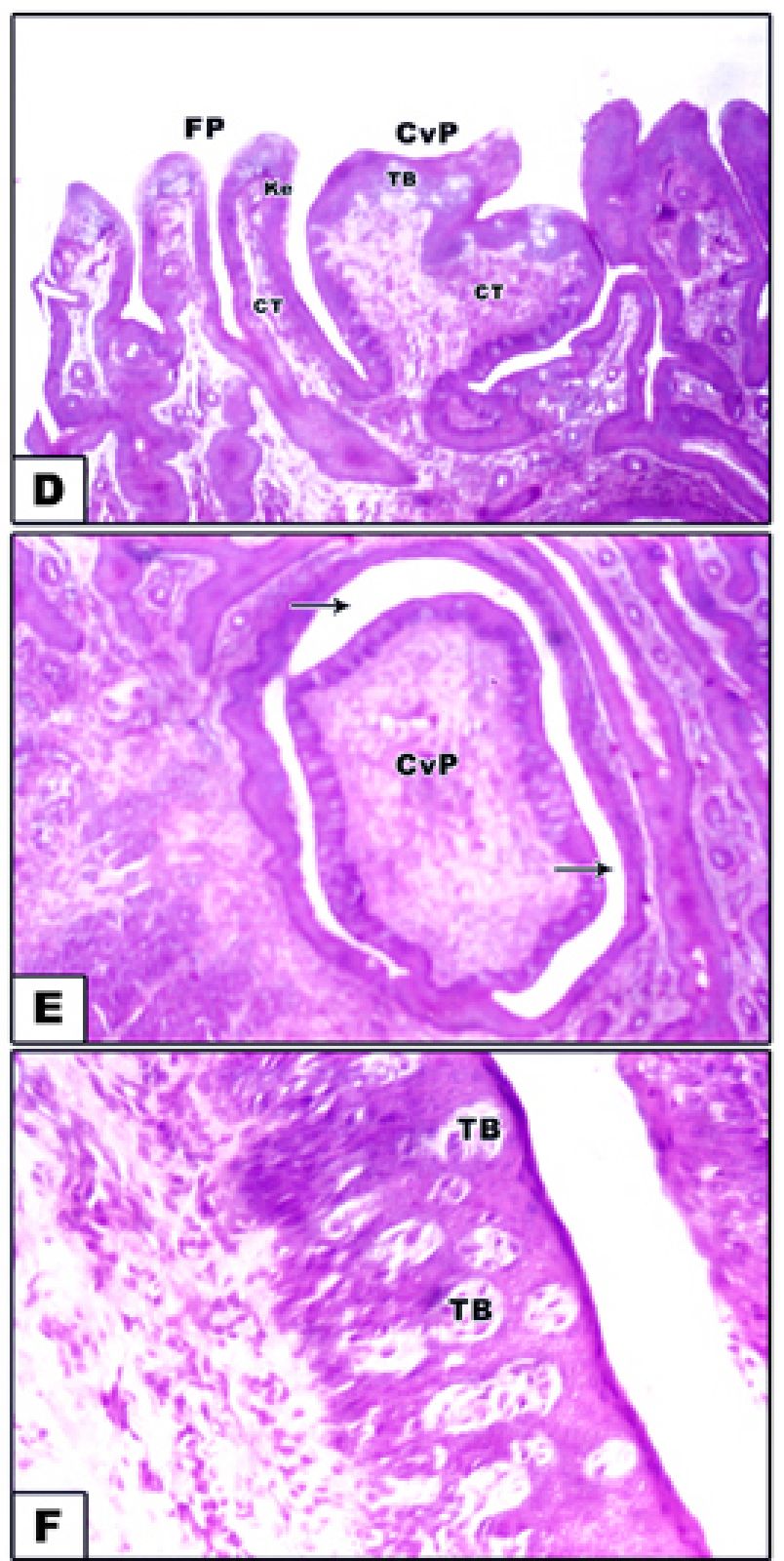

posterior ones remained almost entirely within the mouth. The lingual mucosa characterized by their glandular structure of lingual mucosa and this helps the animal to make a firm attachment of the prey to tongue by the mucoid secretion.

In addition, the forked tongue region is supported by both striated muscle and skeletal cartilage parts outlined by 
branched glandular epithelial cells. The other parts of tongue supported by alternating distribution of upward and downward cartilage rings oriented along the longitudinal axis parallel with longitudinal muscular components. The distributed pattern of cartilage elements facilitated, gliding, elongation and prohension extension as well as sufficient high stiffness to accommodate tongue protrusion. The muscle compensated for the backward forces from the intrinsic tongue elongation and generated positive work.

Similar structural pattern of forked tongue was reported by de Groot et al. (2004) in Python molurus.

Snakes were found to use forked tongues for chemoand mechano-reception (Schwenk, 1995; Bels et al.). During a probing action, the tongue protrudes, oscillates (flicks) while collecting airborne and substrate-fixed chemical particles and subsequently retracts (Ulinski; Gove). In the mouth, chemicals are transported to and stimulate the vomeronasal organ (Young, 1990; Schwenk, 1994, 1995). The pattern of tongue flicking is related to external stimuli, such as the presence of prey or predators, and involves behavioral and seasonal aspects (Gove; Graves \& Halpern, 1990; Bels et al.).

On the other hand the examined T. annularis tongue appeared marked short triangular structure relative to the structure of the oral cavity. Although the modes of feeding varied between both, $T$. annularis is entirely carnivorous and depend mainly on insect feeding and these required fleshy tongue structure.

Except other reptilian species, crocodile tongue, appeared triangular in structure with broad base and rounded apex and intimately fixed to the oral cavity. The tongue exhibited the presence of grooves parallel to tongue apex which facilitated flexion. Fixed tongue and macroscopic structure accommodated the animal for mode of feeding.

Scanning electron microscopic observations, revealed marked variations of lingual structure among the studied reptilian animals. Except the psammophis sibilans which lacked the presence of filiform papillae, radially oblique extension originated from the median sulcus and presence of hemispherical bulges or microfacets and cornified scales aid the animal for engulfing the prey. However the other individuals possessed compact arrangement of the mechanical filiform papillae but their structures varied markedly between the studied species according to their mode of feeding. In Tarentola annularis, the filiform papillae acquired conical shaped structures. The Tarentola annularis characterized by the presence of single apical taste buds per each lingual papilla.
Light microscopic observations revealed that the lingual surface exhibited the presence of different forms of filiform papillae. Each was lined with single cubical epithelium having goblet cells. The filiform papillae revealed the presence of tubular gland containing dense hyaline eosinophilic secretion. Besides, the lining epithelial cells of the interpapillar ridge of filiform papillae exhibited the presence of goblet cells which is the source of mucoid secretion. The mucoid secretion played a great role during capturing of the food materials. Besides, the striations of the dorsal tongue with deep furrow in-between greatly hold internally by muscle strand facilitated great movement of tongue for prey. In addition, the anterior tongue region exhibited irregular distribution of serrated cylindrical filaments either solitary or in groups emerged in between the lingual strands. These serrated filaments possessed highest important function for prey capturer and ingestion of food materials.

Stricking findings were reported in the crocodile tongue which possessed characteristic structures mostly similar to mammalian species especially for the most differentiation of gustatory papillae besides the ordinary structure of the filiform papillae.

The present study confirmed the basic histological features reported by King \& Burke (1997) and Putterill \& Soley (2003) after studying tongue of $C$. niloticus. Shimada et al. (1990) reported that the dorsum tongue of the $A$. mississippiensis is covered with small, evenly distributed cone-shaped filiform papillae spread across the dorsal surface of the tongue. The small, nipple-like surface projections seen in the Nile crocodile probably represent the papillae observed in the American alligator.

Taguchi (1920) described the covering of the tongue as a keratinized stratified squamous epithelium which thickened appreciably towards the body and base of the tongue. In the Crocodylus niloticus keratinized stratified squamous appeared thin and uniform in thickness throughout all regions of the tongue except for localized thickenings containing taste buds

Taguchi observed that mucosal folds divide the surface of the tongue into small, demarcated fields or units. This was confirmed in the present study both macroscopically and more graphically by SEM. Based on surface details provided by SEM, different types of units could be identified. The large units typically situated on the posterior two-thirds of the tongue displayed a large central pore, radiating surface grooves and scattered, peripherally situated dome shaped protrusions. These structures appear to represent the superficial component of specialized taste 
receptors. These observations have not previously been reported.

Taguchi in his study of three crocodilian species mentioned the presence of lingual taste buds but not provided any further detail other than that they were situated between the epithelial cells in the stratum spinosum. Taste buds in the Nile crocodile are associated with localized epithelial thickenings located throughout the tongue, particularly in the lateral and caudo-lateral aspects of the organ. The morphology of the lingual taste buds was similar to that reported for taste buds in the palate and gingivae of the Nile crocodile (Putterill \& Soley, 2004).

Chen et al. (1989) examined the lingual glands of the Chinese alligator, Alligator sinensis and reported that they were either simple tubular or complex acinotubular in nature. They concluded that the glands appeared in the posterior two-thirds of the tongue and functioned as salt secreting glands as well as serving to lubricate food. This investigation on the Nile crocodile identified glandular tissue in a triangular area occupying the posterior two-thirds of the tongue.

The present study revealed the presence of lingual glands opening. The histological structure of the lingual glands observed in the Nile crocodile is similar to that described in C. porosus. Keratinization of the dorsal lingual epithelium has been recognized in higher vertebrates. Among reptiles (Iwasaki, 1990, 1992; Iwasaki et al. 1996a, 1996b; Iwasaki \& Kumakura) the Keratinization of the lingual epithelium occurred, in evolutionary terms, in conjunction with adaptation to dry land from a fresh-water environment.

EL-SAYYAD, H. I. H.; SABRY, D. A.; KHALIFA, S. A.; ABOU-EL-NAGA, A. M. \& FODA, Y. A. Estudios sobre la lengua de las especies de reptiles Psammophis sibilans, Tarentola annularis y Crocodylus niloticus. Int. J. Morphol., 29(4):1139-1147, 2011.

RESUMEN: En el presente estudio fueron utilizados tres diferentes especies de reptiles Psammophis sibilans (Orden Ophidia), Tarentola annularis (Orden Squamata y Crocodylus niloticus (Orden Crocodylia). Sus lenguas fueron removidas y examinadas morfológicamente. Las mucosas linguales se examinaron bajo microscopio electrónico de barrido (SEM) y también procesadas para la investigación histológica. El estudio morfológico macroscópico reveló variaciones de la estructura de la lengua, siendo éstas alargadas con el extremo bifurcado en $P$. sibilans o de estructura triangular aplanada con una base amplia y el borde libre cónico en $T$. annularis o triangular rugosa llenando casi todo el suelo de la cavidad en $C$. niloticus. En el SEM, la mucosa lingual mostró finas ranuras estriadas dispuestas radialmente en la extensión oblicua con pérdida de las papilas linguales. Numerosas microcrestas fueron detectadas por encima de la superficie de las células en P. sibilans. T. annularis exhibiendo una disposición de papilas filiformes cónicas aplanadas y abundante de microcrestas. Sin embargo, en $C$. niloticus, la mucosa lingual posee diferentes tipos de papilas filiformes además de papilas gustativas con una extensa disposición de corpúsculos gustativas. Histológicamente, mediante confirmación de SEM se ilustra la protrusión del epitelio escamoso estratificado de la mucosa lingual en $P$. sibilans y la presencia de corpúsculos gustativos apicales en las papilas filiformes cónicas de T. annularis. La mucosa lingual de C. niloticus reveló diferentes formas de ambas papilas, filiformes y gustativas.

PALABRAS CLAVE: Especies de reptiles; Mucosa lingual; SEM; Microscopía de luz.

\section{REFERENCES}

Bels, V. L.; Chardon, M. \& Kardong, K. V. Biomechanics of the hyolingual system in Squamata. Adv. Comp. Env. Phys., 18:197-240, 1994.

Chen, B.; Tang, J.; Wei, Y. \& Zhang, Z. The lingual glands of the Chinese alligator. Acta Zool. Sin., 35:28-32, 1989.

Cooper, W. E. Jr. Foraging mode and evolution of strike-induced chemosensory searching in lizards. J. Chem. Ecol., 29(4):101326, 2003.

Cooper, W. E. Correlated evolution of prey chemical discrimination with foraging, lingual morphology and vomeronasal chemoreceptor abundance in lizards. Behav. Ecol. Sociobiol., 41(4):257-65, 1997.

de Groot, J. H.; van der Sluijs, I.; Snelderwaard, P. Ch. \& van
Leeuwen, J. L. A three-dimensional kinematic analysis of tongue flicking in Python molurus. J. Exp. Biol., 207(5):827$39,2004$.

Gauthier, J. A.; David, C. C.; de Queiroz, K.; Arnold, K. \& Rowe, T. Tetrapod phylogeny. In: Fernholm, B.; Bremer, K. \& Jorwall, H. (Eds.). The Hierarchy of Life. Amsterdam, Elsevier Science Publishers, 1989. pp.337-53.

Gove, D. A comparative study of snake and lizard tongue-flicking, with an evolutionary hypothesis. Z. Tierpsych., 51(1):58-76, 1979.

Graves, B. M. \& Halpern, M. Roles of vomeronasal organ chemoreception in tongue flicking, exploratory and feeding behaviour of the lizard, Chalcides ocellatus. Anim. Behav., 39(4):692-8, 1990. 
Iwasaki, S. Fine structure of the dorsal lingual epithelium of the lizard, Gekko japonicus (Lacertilia, Gekkonidae). Am. J. Anat., 187(1):12-20, 1990

Iwasaki, S. Fine structure of the dorsal lingual epithelium of the little tern, Sterna albifrons Pallas (Aves, Lari). J. Morphol., 212(1):13-26, 1992.

Iwasaki, S.; Asami, T. \& Wanichanon, C. Fine structure of the dorsal lingual epithelium of the juvenile hawksbill turtle, Eretmochelys imbricata bissa. Anat. Rec., 244(4):437-43, 1996a.

Iwasaki, S.; Asami, T. \& Wanichanon, C. Ultrastructural study of the dorsal lingual epithelium of the soft-shell turtle, Trionyx cartilagineus (Chelonia, Trionychidae). Anat. Rec., 246(3):30516, 1996b.

Iwasaki, S. \& Kumakura, M. An ultrastructural study of the dorsal lingual epithelium of the rat snake, Elaphe quadrivirgata. Ann. Anat., 176(5):455-62, 1994.

King, W. F. \& Burke, R. L. Crocodilian, tuatara species of the world: an online taxonomic and geographic reference. Washington DC, Association of systemic Collection, 1997.

McDowell, S. B. The evolution of the tongue of snakes, and its bearing on snake origins. In: Dobzhansky, T.; Hecht, M. K. \& Steere, W. G. (Eds). Evolutionary Biology. New York, Meredithe Co., 1972.

Putterill, J. F. \& Soley, J. T. General morphology of the oral cavity of the Nile crocodile, Crocodylus niloticus (Laurenti, 1768). I. Palate and gingivae. Onderstepoort J. Vet. Res., 70(4):28197, 2003.

Putterill, J. F. \& Soley, J. T. General morphology of the oral cavity of the Nile crocodile, Crocodylus niloticus (Laurenti, 1768). II. The tongue. Onderstepoort. J. Vet. Res., 71(4):263-77, 2004.

Schwenk, K. Why snakes have forked tongues. Science, 263(5153):1573-7, 1994.

Schwenk, K. Of tongues and noses: chemoreception in lizards and snakes. Trends Ecol. Evol., 10(1):7-12, 1995.

Shimada, K.; Sato, I.; Yokoi, A.; Kitagawa, T.; Tezuka, M. \& Ishii, $\mathrm{T}$. The fine structure and elemental analysis of keratinized epithelium of the filiform papillae analysis on the dorsal tongue in the American alligator (Alligator mississippiensis). Okajimas Folia Anat. Jpn., 66(6):375-91, 1990.

Smith, K. K. \& Mackay, K. A. The morphology of the intrinsic tongue musculature in snakes (Reptilia, ophidia): Functional and phylogenetic implications. J. Morph., 205(3):307-24, 1990.

Taguchi, H. Beiträge zur Kenntnis über die feinere Struktur der Eingeweideorgane der Krokodile. Mitt. Med. Fak. K. Univ. (Tokyo), 25:119-88, 1920.
Ulinski, P. S. Tongue movements in the common boa (Constrictor constrictor). Anim. Behav., 20(2):373-82, 1972.

Young, B. A. Is there a direct link between the ophidian tongue and. Jacobson's organ? Amphibia-Reptilia, 11:263-76, 1990.

\author{
Correspondence to: \\ Hassan I. H. El-Sayyad \\ Experimental embryology Laboratory \\ Zoology Department \\ Faculty of Science \\ Mansoura University \\ Mansoura \\ EGYPT
}

Email: elsayyad@mans.edu.eg

Received: 06-06-2011

Accepted: 02-08-2011 